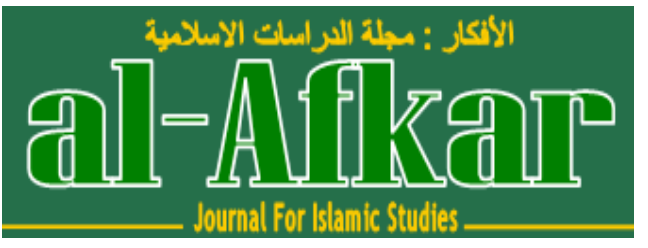

Vol. 2, No. 2, July 2019

P-ISSN : 2614-4883; E-ISSN : 2614-4905

https://al-afkar.com/index.php/Afkar_Journal/issue/view/4

DOI: https://doi.org/10.31943/afkar_journal.v4i1.69

\title{
KETELADANAN GURU DALAM PERSPEKTIF PANDANGAN AL-QUR'AN DAN AL-HADIST MELALUI IMPLEMENTASI KURIKULUM 2013
}

\author{
Jazuli \\ Universitas Muhammadiyah Cirebon \\ E-mail :kacungjauli@yahoo.co.id \\ Sukarso Ghrazianendri \\ Universitas Muhammadiyah Cirebon \\ E-mail : karso.ghrazia123@gmail.com
}

\begin{tabular}{|c|c|c|}
\hline Received & Revised & Accepted \\
\hline 3 Juny 2019 & 20 Juny 2019 & 1 July 2019 \\
\hline
\end{tabular}

\section{THE MODELING OF TEACHER IN THE VIEW OF AL-QURAN AND AL-HADITS THROUGH THE IMPLEMENTATION OF CURRICULUM 2013}

\begin{abstract}
:
This article aims to describe the importance of teacher modeling in the view perspective of the Qur'an and the haditS through the implementation of Curriculum 2013. The teacher modeling is the main key to be the success of education activities by following the globalization challenges. In education, teachers act as an educator, motivator, inspiration, and guidance in developing the attitudes, skills, and knowledge. Exemplary concept based on the Qur'an and Al-Hadith urgent presence for the curriculum in 2013 itself can be integrated which leads directly corresponds to the objectives of the National Education which is to be a man who is faithful and devoted to God Almighty, noble, healthy, knowledgeable, capable, creative, independent, and become citizens of a democratic and responsible. per
\end{abstract}

Keywords: the role of teachers, the Koran, the Hadith, and Curriculum 2013. 


\begin{abstract}
Abstrak:
Artikel ini bertujuan untuk mendeskripsikan pentingnya keteladanan guru dalam perspektif pandangan Alquran dan hadis melalui implementasi Kurikulum 2013. Keteladanan seorang guru menjadi kunci utama untuk mensukseskan kegiatan pendidikan sesuai dengan tantangan globalisasi. Dalam dunia pendidikan guru berperan sebagai pendidik, motivator, inspirator, dan pembimbing dalam mengembangkan sikap, keterampilan, dan pengetahuan. Konsep keteladanan berdasarkan Al-Qur'an dan Al-Hadits sangat urgen keberadaannya agar tujuan dari kurikulum 2013 itu sendiri bisa terintegrasikan yang mengarah secara langsung sesuai dengan tujuan Pendidikan Nasional yaitu agar menjadi manusia yang beriman dan bertaqwa kepada Tuhan Yang Maha Esa, berakhlak mulia, sehat, berilmu, cakap, kretif, mandiri, dan menjadi warga negara yang demokratis dan bertanggung jawab.
\end{abstract}

Kata kunci: peran guru, Alquran, hadis, dan Kurikulum 2013.

\title{
Pendahuluan
}

Guru adalah ujung tombak gerakan perubahan dan dipundaknya dipikul tanggung jawab yang agung dalam membentuk generasi dan mengarahkan para anak didiknya. Seorang guru adalah peletak batu pertama dalam menjadikan sumber daya manusia ahli dan mecetak generasi baik berkualitas. Maka itu diperlukan keteladanan yang baik dan ideal bagi guru agar terwujudnya harapan generasi yang cemerlang dan gemilang. Akan tetapi bila melihat realita yang ada saat ini masih banyak sebagian dari guru yang masih jauh dari keleladanan sebagaiamna mestinya. Guru mengajar sekedarnya saja, bersifat apatis, merasa beban dan terpaksa dalam mengajar, sehingga nilai-nilai keteladanan dan kemuliaan guru hampa. Tentunya hal itu membawa dampak negatif terhadap anak didik yang masih membeutuhkan bimbingan dan keteladanan dari sosok seorang guru. Tingkah laku anak didik adalah cerminan dari apa yang diajarkan oleh guru baik sikap, prilaku, dan keteladanan yang diberikan. Oleh karena itu sudah seharusnya guru menjadikan dirinya teladan yang baik dan ideal. Yang menjadi permasalahan dalam tulisan ini adalah bagaimana menumbuhkan mindset keteladanan guru ideal pada guru dan bagaimana strategi penerapan keteladanan guru ideal berdasarkan Al-Qur'an dan AlHadits yang nantinya terimplementasikan dalam kurikulum 2013 yang pengembangan kurikulunya difokuskan pada kompetensi dan karakter peserta didik, berupa panduan pengetahuan, keterampilan, dan sikap yang dapat didemonstrasikan peserta didik sebagai wujud pemahamabn terhadap konsep yang dipelajarinya secara kontekstual yang pada ahirnya akan menghasilkan peserta didik

\footnotetext{
${ }^{1}$ Ali Miftakhu Rosyad, "The IMPLEMENTASI NILAI-NILAI MULTIKULTURALISME MELALUI PEMBELAJARAN PENDIDIKAN AGAMA ISLAM (THE IMPLEMENTATION OF MULTICULTURALISM VALUES THROUGH LEARNING OF ISLAMIC RELIGION EDUCATION)," Risâlah, Jurnal Pendidikan Dan Studi Islam 5, no. 1 (2019): 1-18.
} 
yang produktif, kreatif, inovatif, avektif; melalui penguatan sikap, keterampilan, dan pengetahuan yang terintegrasi ${ }^{2}$.

Berkaitan dengan hal itu, dalam pandangan Islam yang harus digaris bawahi, salah satu kewajiban seorang guru adalah membersihkan nilai-nilai negatif dan virus-virus jahiliyah dari materi yang diajarkan akan dimintai pertanggungjawabannya di hadapan Allah SWT, dan jangan sampai predikat pahlawan tanda jasa dengan imbalan kecil akan ditambah dengan azab. Umat telah menyerahkan miliknya yang paling berharga dan tambatan jiwa mereka yang tak ternilai kepada guru. Maka kepada para guru, takutlah kepada Allah dalam mendidik generasi bangsa ${ }^{3}$.

Oleh karena itu konsep keteladanan berdasarkan Al-Qur'an dan Al-Hadits sangat urgen keberadaannya agar tujuan dari kurikulum 2013 itu sendiri bisa terintegrasikan yang mengarah secara langsung sesuai dengan tujuan Pendidikan Nasional sebagaimana yang terdapat dalam Undang-undang No. 20 tahun 2003 tentang Sistem Pendidikan Nasional yang di dalam terdapat agar menjadi manusia yang beriman dan bertaqwa kepada Tuhan Yang Maha Esa, berakhlak mulia, sehat, berilmu, cakap, kretif, mandiri, dan menjadi warga negara yang demokratis dan bertanggung jawab.

\section{Landasan Teori}

\section{Pengertian Guru}

GURU adalah front terdepan dalam pelaksanaan pendidikan. Operasional pendidikan pada tingkatan mikro atau lapis dasar (gras root) adalah ditingkat institusional atau satuan pendidikan dan instruksional. Namun ada kecenderungan guru tersisihkan dari peranannya sebagai pihak yang terdepan, termasuk kaitannya dengan UNBK, UNAS, UAS-BN atau apapun namanya.Padahal pada tingkat ini pendidikan berlangsung di front yang paling depan dimana terjadi interaksi langsung antara pendidik dan peserta didik dalam interasi pendidikan, serta berada pada posisi yang paling dekat dengan orang tua atau wali murid dan masyarakat.

Dalam posisi ini orang tua dan masyarakat dapat mengamati dari dekat bagaimana berlangsungnya pendidikan untuk anak-anak mereka. Guru sebagai pihak yang berada ditingkat instruksional berhadapan langsung dengan peserta didik dalam proses instruksional harus memperoleh otonomi pedagogis dan profesional untuk melaksanakan tugas-tugas sebagai pendidik. Guru sebagai perancang pengajaran, manager pengajaran, pengarah pembelajaran, pembimbing

\footnotetext{
2 Ibnu Rusydi, "Paradigma Pendidikan Agama Integratif-Transformatif," Jurnal Pendidikan Islam, 1970, https://doi.org/10.14421/jpi.2011.11.105-120.

${ }^{3}$ Ali Miftakhu Rosyad, “Al-Afkar, Journal for Islamic Studies URGENSI INOVASI PEMBELAJARAN DALAM PENDIDIKAN AGAMA ISLAM Al-Afkar, Journal for Islamic Studies THE URGENCY OF LEARNING INNOVATION ON ISLAMIC RELIGIOUS STUDY" 3, no. 1 (2019), https://doi.org/10.5281/zenodo.2546882.
} 
peserta didik dan penilai hasil belajar, maka merekalah yng sesungguhnya mempunyai otonomi dalam memberikan informasi hasil belajar, tapi kenyataan hingga saat ini guru lebih banya diperlakukan sebagai komponen obyek dan bukan sebagai subyek insan pendidikan. Sudah seharusnya guru memperoleh preoritas sentral dalam pemberdayaan otonomi pedagogisnya dalam mewujudkan kinerja pendidikan. Mengingat besarnya peran guru pada tingkat institusional dan instruksional, maka guru harus dijadikan sumber informasi proses dan hasil pendidikan dari anak didik yang menjadi tanggung jawabnya. Guru harus diberdayakan dalam keikutsertaannya dalam evaluasi dan proses pembelajaran.

\section{Peran Guru Secara Pribadi}

Dilihat dari dirinya sendiri, seorang guru harus berperan sebagai berikut :

1. Petugas social, yaitu seorang yang harus membantu untuk kepentingan masyarakat. Dalam kegiatan-kegiatan masyarakat guru senantiasa merupakan petugas-petugas yang dapat dipercaya untuk berpartisipasi didalamnya.

2. Pelajar dan ilmuwan, yaitu senantiasa terus menerus menuntut ilmu pengetahuan. Dengan berbagai cara setiap saat guru senantiasa belajar untuk mengikuti perkembangan ilmu pengetahuan

3. Orang tua, yaitu mewakili orang tua murid di sekolah dalam pendidikan anaknya. Sekolah merupakan lembaga pendidikan setelah keluarga, sehingga dalam arti luas sekolah merupakan keluarga, guru berperan sebagai orang tua bagi siswanya.

4. Pencari teladan, yaitu yang senantiasa mencarikan teladan yang baik untuk siswa. Guru menjadi ukuran bagi norma-norma tingkah laku

5. Pemberi keamanan, yaitu yang senantiasa mencarikan rasa aman bagi siswa. Guru menjadi tempat berlindung bagi siswa untuk memperoleh rasa aman dan puas di dalamnya ${ }^{4}$.

\section{Peran Guru dalam Upaya Peningkatan Kualitas Belajar Siswa}

Salah satu tugas utama guru adalah pelaksanaan pembelajaran di dalam kelas, pembelajaran dapat diartikan sebagai kegiatan yang ditujukan untuk membelajarkan siswa. Dalam proses pembelajaran sering ditemui adanya kecenderungan meminimalkan keterlibatan siswa. Dominasi guru dalam proses pembelajaran menyebabkan kecenderungan siswa lebih bersifat pasif sehingga mereka lebih banyak menunggu sajian guru dari pada mencari dan menemukan sendiri pengetahuan, ketrampilan atau sikap yang mereka butuhkan.

\footnotetext{
${ }^{4} \mathrm{U}$ Abdullah Mumin, "PENDIDIKAN TOLERANSI PERSPEKTIF PENDIDIKAN AGAMA ISLAM (TELAAH MUATAN PENDEKATAN PEMBELAJARAN DI SEKOLAH)," Al-Afkar, Journal For Islamic Studies 2, no. 1 (2018): 15-26.
} 
Proses pembelajaran yang selama ini dilakukan khususnya pada sekolah yang berada di pedesaan atau daerah yang belum tersentuh teknologi pada dasarnya hanya menekankan pada target pencapaian kurikulum dari pada mengembangkan kemampuan belajar dan membangun individu. Kondisi seperti ini tidak akan mampu menumbuhkembangkan aspek kemampuan dan aktivitas siswa seperti yang diharapkan. Dengan diterapkannya Kurikulum 2006 (KTSP), guru tidak lagi hanya sebagai penceramah yang selalu mendokrtrinasi berbagai macam teori kepada siswa. Siswa tidak lagi diperlakukan sebagai objek namun secara utuh mereka merupakan subjek yang siap untuk menyerap berbagai pengalaman melalui proses pembelajaran yang menarik dan menyenangkan. Guru dan siswa harus menciptakan kelas sebagai suatu keluarga kecil yang mampu memberikan gambaran tentang proses interaksi di dalamnya, dimana siswa lebih berpartisipasi aktif sehingga kegiatan siswa dalam belajar jauh lebih dominan dari pada kegiatan guru dalam mengajar. Penjelasan pasal 4 UU. No. 14 Tahun 2005 menjelaskan bahwa guru merupakan agen pembelajaran, yaitu guru berperan sebagai fasilitator, motivator, pemacu, perekayasa pembelajaran, dan pemberi inspirasi belajar bagi peserta didik.

\section{PENGERTIAN KETELADANAN DALAM ISLAM}

Keteladanan adalah teknik pendidikan yang paling baik, dan oleh karena itu mendasarkan pendidikan di atas dasar demikian, seorang anak harus memperoleh teladan dari keluarga dan orang tuanya agar ia semenjak kecil sudah menerima norma-norma Islam dan berjalan berdasarkan konsepsi yang tinggi itu. Manusia harus memperoleh suri tauladan dari dalam masyarakat untuk membina mereka dengan sifat dan adat istiadat yang dikehendaki Islam ${ }^{5}$.

Al-uswah berarti teladan. Imam 'Asim (salah satu imam qurra') membaca lafadz al-uswah dengan dhammah pada hamzah. Sedangkan imam-imam lain membaca kasrah pada hamzah (iswah). Keduanya adalah dua pandangan yang berbeda. Namun, menurut Imam Farra', bentuk jamak dari lafadz tersebut tetap sama (yaitu: usan). Adapun alasan mengapa pendapat kedua mendhammah hamzah ketika jamak (iswah menjadi usan, bukan isan) adalah untuk membedakan lafadzlafadz yang mengandung huruf wawu dan lafadz- lafadz yang mengandung huruf ya'.

Terkait hal tersebut, al-Jauhary menjelaskan: Uswah dan iswah adalah dua pendapat yang berbeda. Bentuk jamak dari keduannya juga berbeda, usan dan isan. Uqbah bin Hasan al Hajary meriwayatkan dari Anas bin Malik dari Nafi'dari

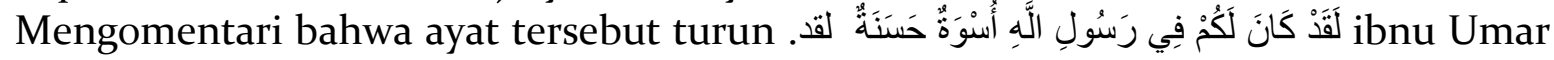
pada hal laparnya Nabi (bukan perangnya Nabi). Begitulah Khatib Abu Bakar Ahmad memparkan hadits tersebut. Beliau menambahkan, hanya Uqbah sendiri yang

\footnotetext{
${ }^{5}$ Amin Ridwan, "Peran Guru Agama Dalam Bimbingan Konseling Siswa Sekolah Dasar," Risâlah, Jurnal Pendidikan Dan Studi Islam 4, no. 1 (2017): 1-13.
} 
meriwayatkan hadits ini dari Malik, tidak ada riwayat lain. Dan ini adalah satusatunya sanad yang beliau tulis dari hadits tersebut ${ }^{6}$.

Al-uswah berarti panutan. Sesuatu yang dicontoh. Sesuatu yang terpuji, kemudian dicontoh baik dalam amal perbuatannya maupun ahwalnya. Ketika itu, wajah beliau terluka. Salah satu gigi beliau patah. Ditambah lagi paman beliau alQurthubi, al-Jami' li Ahkam al-Qur'an..., Hamzah gugur dalam perang, dan beliau sendiri dalam keadaan lapar. Namun beliau tetap bersabar, bersyukur, dan menerima situasi tersebut dengan ikhlas. Anas bin Malik meriwayatkan dari Abi Thalhah, beliau berkata: "Kami mengadu kepada Nabi bahwa kami lapar. Kemudian kami serempak mengangkat (menunjukkan) batu (pengganjal lapar) yang ada pada perut kami. Maka Nabipun mengangkat dua buah batu yang beliau letakkan pada perutnya (menunjukkan bahwa beliau lebih lapar dari mereka)".

Bagaimana hukum meneladani Rasulullah SAW. wajib atau sunnahkah?. Para ulama berbeda pendapat mengenai hal ini. Ada dua pendapat. Pendapat pertama mengatakan wajib, yang mana kemudian bisa berubah menjadi sunnah ketika ada qarinah atau dalil. Sebaliknya, pendapat kedua mengatakan bahwa hukum meneladani Rasulullah SAW. adalah sunnah. Kemudian bisa berubah menjadi wajib ketika terdapat qarinah atau dalil. Dari sini, mungkin dapat diambil hipotesis bahwa hukum meneladani Rasulullah dalam hal agama adalah wajib, sedangkan hukum meneladani beliau dalam urusan dunia adalah sunnah. 87 al-Qurthubi, al-Jami' li Ahkam al-Qur'an..., 143.

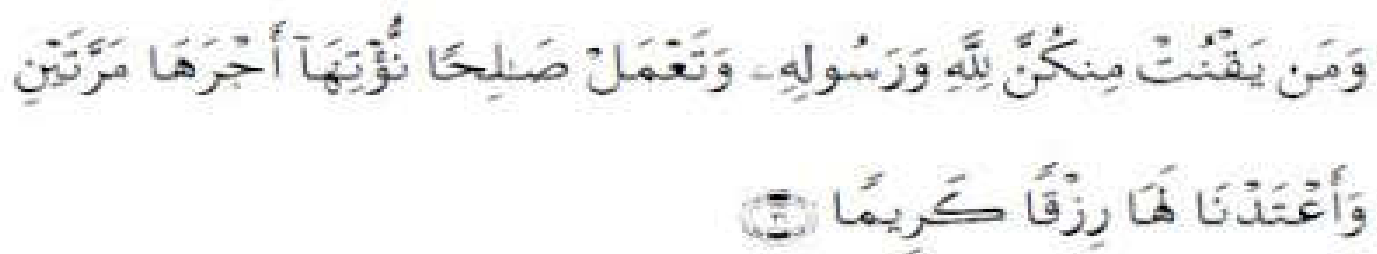

Dalam pendidikan, nasehat saja tidaklah cukup bila tidak disertai dengan keteladanan dan perantara yang memungkinkan keteladanan itu diikuti dan diteladani. Nasehat yang jelas yang dapat dipegang adalah nasehat yang dapat menggantung perasaan dan tidak membiarkan perasaan itu jatuh kedasar dan mati tak bergerak. Bila keteladanan itu baik, maka nasehat akan sangat berpengaruh didalam jiwa, dan akan menjadi suatu yang sangat besar dalam pendidikan rohani.

Selanjutnya keteladanan itu dari segi lain mutlak diperlukan. Hal itu dikarenakan dalam jiwa terdapat berbagai dorongan yang terus-menerus memerlukan pengarahan dan pembinaan. Ini memerlukan adanya nasehat atau kadang-kadang ada orang yang bisa langsung mengerti nasehat yang baik, tetapi ada pula yang tidak cepat mengerti kalau hanya nasehat saja.

\footnotetext{
${ }^{6}$ Rosyad, “The IMPLEMENTASI NILAI-NILAI MULTIKULTURALISME MELALUI PEMBELAJARAN PENDIDIKAN AGAMA ISLAM (THE IMPLEMENTATION OF MULTICULTURALISM VALUES THROUGH LEARNING OF ISLAMIC RELIGION EDUCATION)."
} 
Menurut DN. Madley (1979) "Salah satu proses Asumsi yang melandasi keberhasilan guru dan pendidikan guru adalah penelitian berfokus pada sifat-sifat kepribadian guru. Kepribadian guru yang dapat menjadi suri teladanlah yang menjamin keberhasilannya mendidik anak". Utamanya dalam pendidikan Islam seorang guru yang memiliki kepribadian baik, patut untuk ditiru peserta didik khususnya dalam menanamkan nilai-nilai Agamis, Haidar Putra Daulay, mengemukakan salah satu komponen kompetensi keguruan adalah: "Kompetensi moral akademik, seorang guru bukan hanya orang yang bertugas untuk mentransfer ilmu (Transfer Knowledge) tetapi juga orang yang bertugas untuk mentransfer nilai (Transfer of Value). Guru tidak hanya mengisi otak peserta didik (Kognitif) tetapi juga bertugas untuk mengisi mental mereka dengan nilai-nilai baik dan luhur mengisi Afektifnya”.

Pendidikan agama Islam memegang peran sentral karena memproses manusia untuk memiliki keseimbangan religius-spirit. Islam sangat memperhatikan pendidikan dan menganjurkan kepada para pendidikan untuk betul-betul mendidik peserta didik secara baik. Sebab bila peserta didik terbiasa dengan kebaikan maka akan menjadi orang baik pula. Oleh karena itu sangat penting mendidik kepribadian peserta didik dengan memberikan contoh keteladanan yang berawal dari diri sendiri. Sesuai dengan keteladanan yang di contohkan oleh Rasulullah SAW, sebagai guru pertama bagi umat Islam.

\section{Aspek-Aspek Keteladanan Guru}

Menjadi guru teladan merupakan suatu proses pembelajaran seorang guru untuk mendapatkan kesempurnaan dan keridhaan Allah SWT dalam ilmu yang di miliki. Secara sederhana menjadi guru teladan adalah kemampuan seorang guru dalam mendapatkan sumber ilmu yang diajarkan dengan cara memberdayakan diri agar mendapatkan kebaikan dari sisi Allah SWT. Yaitu seorang guru mampu meningkatkan kemampuan fungsi panca indra dan otak, dengan kemampuan intuisi dan hatinya ${ }^{7}$.

Islam menganjurkan kepada para pendidik agar membiasakan peserta didik dengan etika dan akhlak Islam karena demikian itu termasuk kaidah yang dibuat Islam untuk mendidik siswa agar interaksi siswa dengan orang lain selalu dibangun diatas akhlak yang mulia. Sebaiknya seorang pendidik banyak belajar tentang hakekat dan makna mendidik, baik dari Al-Qur'an maupun sunnah Rasulullah SAW.

\section{Keteladanan berbuat jujur.}

\footnotetext{
${ }^{7}$ Ali Miftakhu Rosyad et al., "SMP N2 Juntinyuat 2 Universitas Negeri Yogyakarta THE ACTUALIZATION OF CHARACTER EDUCATION BASED ON SCHOOL CULTURE IN SOCIAL STUDIES LEARNING IN JUNIOR HIGH SCHOOL," Harmoni Sosial: Jurnal Pendidikan IPS 5, no. 1 (2018): 79-92, http://journal.uny.ac.id/index.php/hsjpi.
} 
Memberi teladan berbuat jujur dilakukan guru dengan cara berbicara sesuai kenyataan yang dilakukan guru saat berada di kelas maupun diluar kelas. Kemudian Guru selalu mengingatkan siswa apabila bersalah harus minta maaf dan memberi teguran langsung apabila ada siswa ada yang bertengkar. Selain itu guru juga selalu memberikan motivasi agar anak berbuat jujur saat mengerjakan soal-soal. Keteladanan tersebut dilakukan guru untuk menumbuhkan karakter jujur pada siswa. Jujur harus dibiasakan dalam kehidupan sehari-hari sehingga sifat itu akan tertanam pada diri kita dengan sendirinya. Menerapkan sikap jujur sebenarnya tidaklah sulit. Agar selalu berada dijalan yang benar yang diridhoi Allah SWT maka harus dimulai dengan niat yang sungguh sungguh dan dibiasakan dalam kehidupan sehari-hari sehingga sifat itu akan tertanam pada diri kita dengan sendirinya. Jika siswa berada di lingkungan masyarakat yang kondusif, maka juga akan memberikan kebiasaan pada siswa untuk selalu bersikap jujur. Dengan memberikan keteladanan bersikap jujur maka dalam dirisiswa akan tumbuh secara perlahan dan bisa menjadi kebiasaan yang tidak mudah hilangdari dalam diri siswa itu sendiri.

\section{Menanamkan keteladanan bersikap disiplin.}

Guru memberikan teladan bersikap disiplin dengan cara datang kesekolah lebih awal sebelum jam masuk kelas guru sudah tiba di sekolah, ketepatanan lokasi waktu saat mengajar, dan memberikan teladan memakai seragam sesuai ketentuan dan rapi. Keteladanan tersebut dimaksudkan untuk menanamkan karakter disiplin pada siswa. Disiplin merupakan suatu kondisi yang menunjukan nilai-nilai ketaatan pada aturan.Disiplin akan membuat sesorang tahu dan dapat membedakan hal-hal yang boleh dilakukan dan tak sepantasnya dilakukan ${ }^{8}$.

\section{Keteladanan akhlak mulia.}

Keteladanan akhlak mulia ditanamkan untuk mengembangkan karakter religius pada siswa.Untuk mengembangkan keteladanan akhlak mulia, guru membimbing siswa untuk kegiatan Baca Al-Quran dan menghafal 2 ayat setiap pagi sebelum masuk kelas, kemudian guru selalu menerapkan sebelum dimulai pelajaran dengan membaca Al-Fatihah dan doa belajar kemudian di akhir pembelajaran ditutup dengan doa penutup majelis. Selanjutnya untuk membentuk akhlak mulia, guru memberikan bimbingan kegiatan sholat dhuha dan sholat dhuhur yang dilaksanakan setiap hari. Pemberian keteladanan akhlak mulia ini berdampak baik bagi siswa, karena siswa meneladani apa yang dilakukan maupun dicontohkan guru dalam kehidupan sehari-hari. Dengan demikian keteladanan akhlak dapat diartikan sebagai usaha sungguh-sungguh dalam rangka membentuk karakter religius.

\footnotetext{
${ }^{8}$ Mumin, "PENDIDIKAN TOLERANSI PERSPEKTIF PENDIDIKAN AGAMA ISLAM (TELAAH MUATAN PENDEKATAN PEMBELAJARAN DI SEKOLAH)."
} 
Jajuli \& Sukarso Ghrazianendri

Keteladanan Guru dalam Perspektif Pandangan......

\section{Keteladanan menunjukkan kecerdasannya.}

Kecerdasan sangat diperlukan karena tidak mungkin guru bisa mengajar hanya dengan asal-asalan tanpa adanya bekal ilmu yang memadai. Keteladanan ini untuk mengembangkan karakter kesopanan, tanggung jawab dan kreatif. Keteladanan yang dilakukan guru yaitu mengajarkan untuk berperilaku sopan dengan memberikan pesan moral saat berbicara tidak melotot dan tidak bersuara keras, kemudian mampu menguasai materi yang disampaikan saat mengajar, selain itu guru juga mampu menciptakan pembelajaran yang menyenangkan dengan memadukan antara diskusi, tanya jawab, atau dengan mengerjakan soal latihan dan dapat juga diselingi dengan menyanyi saat pembelajaran agar siswa tidak merasabosan. Guru haruslah bersikap bijak dan sekreatif mungkin agar disenangi murid-muridnya. Jiwa yang kreatif terlahir dari sebuah pemikiran guru yang selalu ingin berinovasi sehingga selalu bervariasi dalam memberikan materi kepada anak didiknya.

\section{Keteladanan menunjukkan sikap mandiri dan bekerja keras.}

Mandiri dan bekerja keras sangat erat kaitannya, karena dengan perilaku siswa yang mampu bekerja keras akan membentuk sikap kemandirian yang tidak selalu bergantung kepada orang lain. Guru memberikan keteladanan bersikap mandiri dan bekerja keras dengan selalu memberikan motivasi, pesan moral dan bimbingan apabila siswa merasa kesulitan, kemudian melibatkan peserta didik agar aktif dalam pembelajaran, selain itu guru memberikan teladan dengan selalu giat dan bersemangat dalam mengajar. Keteladanan ini berhasil diterapkan pada siswa karena siswa sudah mampu mengerjakan soal dengan mandiri, siswa bersikap antusias, aktif, dan semangat dalam belajar.Terkait dengan pelaksanaan keteladanan yang diterapkan ${ }^{9}$.

Agar semangat kerja keras selalu ada dalam diri, maka hendaknya kita beranggapan akan hidup selamanya. Namun dalam hal ibadah khusus, seperti shalat, hendaknya kita beranggapan bahwa seolah-olah kita akan mati esok hari sehingga kita bisa beribadah dengan khusyu'. Hal ini sesuai dengan pesan Rasulullah SAW:

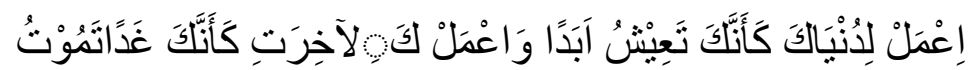

Artinya: "bekerjalah untuk kepentingan duniamu seolah-olah engkau hidup selama-lamanya; dan bekerjalah untuk kepentingan akhiratmu seolah-olah engkau akan mati esok hari”. (H.R. Ibnu Asakir).

Al-Maghribi bin as-said al-maghribi dalam buku, Begini seharusnya mendidik anak, mengemukakan kriteria-kriteria seorang pendidik teladan menurut Al-Qur'an dan sunnah Rasulullah SAW adalah sebagai berikut; Pemaaf dan tenang, Lemah

${ }^{9}$ Ridwan, “Peran Guru Agama Dalam Bimbingan Konseling Siswa Sekolah Dasar." 
lembut dan menjauhi sifat kasar dalam bermuamalah, Berhati penyayang, Ketaqwaan, Selalu berdo'a untuk anak, Lemah lembut dalam bermuamalah dengan anak, Menjauhi sikap marah, Bersikap adil dan tidak pilih kasih.

Mengingat begitu penting guru dalam pendidikan, maka guru dituntut untuk memiliki kriteria-kriteria yang telah disebutkan diatas. Guru merupakan figur atau tokoh panutan peserta didik dalam mengambil semua nilai dan pemikiran tanpa memilih antara yang baik dengan yang buruk. Peserta didik memandang bahwa guru adalah satu-satunya sosok yang sangat disanjung. Maka didikan dari guru berpengaruh besar dalam memilih andil dalam membentuk kepribadian dan pemikiran peserta didik. Pendidik atau guru merupakan bagian pendidikan yang langsung berinteraksi dan bertanggung jawab dalam pengolahan sumber daya manusia. Secara langsung mengubah pola pikir dan meningkatkan prosuktifitas peserta didik melalui ilmu yang dikembangkan secara bersama-sama dengan komponen pendidikan lain. Oleh pendidikan dibuat lebih kreatif dalam memecahkan permasalahan peserta didik secara efektif dan efisien. Sehingga secara langsung maupun tidak langsung mampu mendorong kemajuan peserta didik.

Maman Faturrohman dalam buku Al-qur'an pendidikan dan pengajaran. Mengemukakan kondisi ideal pendidik dan pengajar, antara lain :

- Telah mendapat pendidikan atau pengajaran. Seorang pendidik dan pengajar idealnya adalah seorang yang telah mendapat pendidikan atau pengajaran sebelum menjadi guru.

- Benar-benar menguasai ilmu. Seorang pendidik dan pengajar, idealnya adalah seorang yang benar-benar menguasai ilmu, khususnya ilmu yang akan disampaikan kepada peserta didik. Sudah benar-benar menjiwai ilmu tersebut dan kebenaran ilmu teruji, termasuk oleh orang-orang di sekitar pendidik.

\section{PERILAKU SISWA DALAM KAITANNYA DENGAN KETELADANAN GURU}

Setiap lembaga pendidikan memiliki tujuan yang sama yaitu membentuk manusia cerdas baik jasmani maupun rohani. Tujuan ini dapat tercapai atau tidak, tak dapat di ukur tanpa peserta didik atau siswa. Maka sasaran utama pendidikan adalah manusia dalam hal ini peserta didik, begitu pun manusia atau siswa sangat membutuhkan pendidikan fitrah rasa ingin tahu yang dimiliki. Jadi ada keterkaitan timbal balik antara siswa dan pendidikan.

Pendidikan adalah suatu proses dalam rangka mempengaruhi siswa agar dapat menyesuaikan diri sebaik mungkin terhadap lingkungan dan dengan demikian akan menimbulkan perubahan dalam diri peserta didik. Perubahan ini merupakan ciri-ciri dasar dari pertumbuhan dan perkembangan yang dialami peserta didik. Oemar Hamalik dalam bukunya Proses Belajar Mengajar, mengemukakan bahwa konsepkonsep dasar yang berkenaan dengan perkembangan siswa antara lain : Pertumbuhan, Kematangan, Kedewasaan, Perkembangan, dan Perkembangan normal 
Perkembangan ini juga tidak lepas dari pengaruh luar maupun dalam diri siswa. Sebab manusia ditentukan oleh lingkungan karena proses interaksi terus menerus antara individu dengan lingkungannya.

Faktor dalam diri siswa adalah bakat, sedangkan faktor dari luar adalah lingkungan. Faktor dari dalam dan dari luar ini saling berkaitan dan saling mempengaruhi satu sama lain. Kendatipun tidak dapat ditolak tentang adanya kemungkinan dimana pertumbunhan dan perkembangan itu semata-mata hanya di sebabkan oleh faktor bakat saja atau oleh lingkungan saja.

Faktor dalam dan luar yang dijelaskan di depan menjadi sebab akibat timbulnya perilaku dari seseorang siswa, baik itu perilaku negatif maupun positif. Perilaku negatif siswa timbul bila kedua faktor tidak seimbang dan seiring dalam mempengaruhi perkembangan siswa atau salah satunya lebih dominan. Faktor dari luar ini begitu besar dan banyak sebab seiring dengan zaman semakin maju dan teknologi baru semakin canggih, serta modern dan merupakan fitrah manusia selalu ingin mencoba hal baru. Allah SWT berfirman :

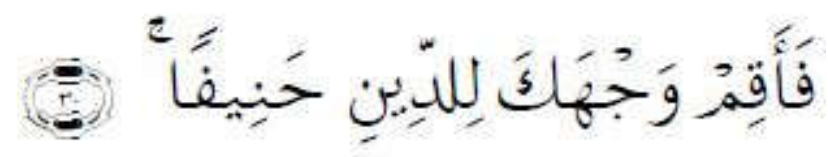

Terjemahannya : "Maka hadapkanlah wajahmu kepada agama yang lurus ......”

Hal-hal baru ini yang berupa kemajuan teknologi, memberikan pengaruh negatif bagi siswa. Seperti tontonan-tontonan yang menggugah moral peserta didik menjadi malas, membantah orang tua, dan bahkan tidak jarang kita dapatkan peserta didik yang senang menyakiti teman, saudara atau orang lain. Terlebih lagi jika siswa tinggal dalam lingkungan yang tidak mengedepankan agama sebagai landasan utama dalam hidup bermasyarakat.

Pengaruh-pengaruh yang ada ini dapat diatasi dengan adanya guru sebagai pengontrol, pembimbing dan pendidik bagi peserta didik. Pendidikan yang diberikan guru bukan hanya menyangkut materi atau pengetahuan saja. Tapi juga tingkah laku, akhlak serta kepribadian. Karena sekolah merupakan rumah kedua bagi peserta didik dan sebagian besar dari waktu dihabiskan di sekolah bersama teman-teman serta guru. Pendidikan memberikan pengetahuan yang belum diketahui peserta didik, meluruskan atau memperbaiki kesalahan peserta didik serta membimbing pengetahuan yang dimiliki peserta didik agar menjadi lebih cerdas lagi.

Maman Faturrohman dalam buku Al-Qur'an Pendidikan dan Pengajaran, berpendapat bahwa :

"Berdasarkan berbagai definisi tentang pendidikan itu, dapat ditarik pandangan umum tentang pendidikan bahwasanya pendidikan adalah sebuah proses yang dilakukan secara sadar dan dilakukan oleh pendidik terhadap peserta didik, baik secara langsung maupun tidak langsung yang bertujuan memberikan pengaruh, bimbingan, dan atau 
arahan agar peserta didik menjadi dewasa dan sanggup berperan dengan tepat di masa yang akan datang,dan proses ini umumnya terjadi sepanjang hayat."

Adapun perilaku-perilaku yang diharapkan dapat dimiliki peserta didik setelah menjalani proses pendidikan, yaitu :

- Siswa menjadi manusia Bertaqwa dan beriman kepada Allah SWT. Taqwa dilahirkan dan dipupuk oleh ibadah. Dan ibadah ditumbuhkan oleh Iman kepada Allah SWT. Dari Iman itulah tersusun syariat (peraturan) melaksanakan ibadah. Allah memerintahkan supaya mentaati-Nya dan RasulNya, yaitu suatu perintah yang mengandung kebencian dan beban memberatkan.

- Membentuk Pribadi Siswa yang berakhlak Karimah. Pembinaan akhlak yang mulia merupakan inti ajaran Islam sebagaimana terdapat dalam Al-Qur'an, akhlak ini bertumpu dalam keimanan kepada Allah SWT. Dan keadilan sosial.

- Cerdas Jasamani dan Rohani. Sistem Pendidikan Nasional merumuskan tujuan pendidikan adalah usaha sadar untuk menyiapkan peserta didik melalui kegiatan bimbingan, pengajaran dan atau latihan bagi peranan peserta didik dimasa yang akan datang. Ini sejalan dengan tujuan Pendidikan Nasional menurut UU No. 2 tahun 1989. Ki Hajar Dewantara tokoh Pendidikan Nasional, merumuskan hakekat Pendidikan sebagai usaha orang tua bagi anak-anak dengan maksud menyokong kemajuan hidupnya, dalam arti memperbaiki tumbuhnya kekuatan rohani dan jasmani yang ada pada anak-anak.

- Mampu mengaktualisasikan diri yang baik di dalam bermasyarakat. Allah menciptakan manusia sebagai makhluk sosial maka manusia tidak bisa hidup sendiri, karena itu semua dididik untuk bisa hidup bermasyarakat sesuai dengan ajaran Islam.

Perilaku-perilaku diatas seyogiyanya dapat dimiliki peserta didik, dan ini adalah tugas pendidik sebagai teladan bagi siswa. Sukses tidaknya seorang pendidik adalah dilihat dari hasil didikan seorang pendidik. Pendidik yang sukses akan mengikat peserta didik dengan nilai-nilai universal dan menjauhkan peserta didik dari pengaruh budaya dan pemikiran yang merusak. Sebagai seorang guru yang mempunyai tugas dan tanggung jawab untuk mendidik peserta didik dalam mengembangkan kepribadian, guru dituntut memiliki kepribadian ideal yang patut untuk dicontoh. Peserta didik tidak akan mudah untuk tergugah hati dan pikiran atas ajaran pendidik, bila tidak melihat bukti aktualisasinya pada diri pendidik. Sebagai contoh siswa tidak akan disiplin dalam mengikuti pelajaran guru yang sering terlambat masuk dan memulai pelajaran.

Mohammad Surya dalam buku Percikan Perjuangan Guru, mengemukakan hal berikut : 
"Pada umumnya siswa sangat mengidamkan gurunya memiliki sifat-sifat yang ideal sebagai sumber keteladanan, bersikap ramah dan penuh kasih sayang, penyabar, menguasai materi ajar, mampu mengajar dengan suasana menyenangkan, dsb.”

Dengan berbagai penjelasan di atas, dapat disimpulkan bahwa perilaku siswa sangat erat kaitannya dengan keteladanan yang dimiliki guru. Karena seorang guru yang teladan akan mudah menggugah, mempengaruhi siswa untuk lebih giat belajar dan berusaha menciptakan perilaku yang baik dalam pribadinya. Sebagaimana yang telah dicontohkan guru sesuai dengan tuntunan profesional, guru harus memiliki kualitas kepribadian yang sedemikian rupa sebagai pribadi panutan.

Kegiatan pendidikan dalam garis besarnya dapat dibagi tiga: Kegiatan pendidikan oleh diri sendiri, Kegiatan pendidikan oleh lingkungan, dan Kegiatan pendidikan oleh orang lain terhadap orang tertentu.

Adapun binaan pendidikan dalam garis besarnya mencakup tiga daerah: Daerah jasmani, Daerah akal, Daerah hati.

Tempat pendidikan juga ada tiga yang pokok: Di dalam Rumah Tangga, Masyarakat, dan Sekolah.

Oleh karena itu sangat penting mendidik kepribadian peserta didik dengan memberikan contoh keteladanan yang berawal dari diri sendiri. Sesuai dengan keteladanan yang di contohkan oleh Rasulullah SAW, sebagai guru pertama bagi umat Islam. Dan sejalan dengan Firman Allah SWT:

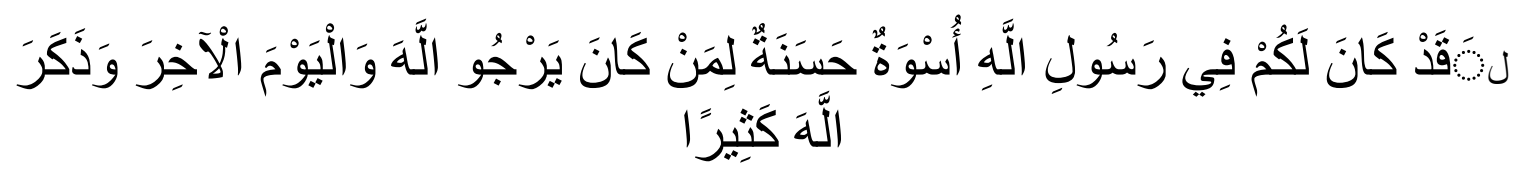

Terjemahnya : "Sesungguhnya Telah ada pada (diri) Rasulullah itu suri teladan yang baik bagimu (yaitu) bagi orang yang mengharap (rahmat) Allah dan (kedatangan) hari kiamat dan dia banyak menyebut Allah".

Upaya guru pendidikan agama Islam mendidik peserta didik agar menjadi manusia berakhlakul karimah, adalah tidak lepas dari kepribadian yang dimiliki oleh guru.Yaitu sifat teladan seorang pendidik untuk dapat menjadi panutan dan contoh bagi peserta didik dalam banyak segi. Hal ini telah sering ditekankan dalam Islam, dan Rasulullah SAW. Menjadi contoh teladan (Uswatun Hasanah) pertama.

\section{IMPLEMENTASI KURIKULUM 2013.}

Konsep inti Kurikulum 2013 adalah bahwa Proses pembelajaran menyentuh tiga ranah, yaitu: sikap, pengetahuan, dan keterampilan dan hasil belajar melahirkan peserta didik yang produktif, kreatif, inovatif, dan afektif melalui penguatan sikap, keterampilan, dan pengetahuan yang terintegrasi 
Ranah sikap menggamit transformasi substansi atau materi ajar agar peserta didik "tahu mengapa".

Ranah keterampilan menggamit transformasi substansi atau materi ajar agar peserta didik "tahu bagaimana".

Ranah pengetahuan menggamit transformasi substansi atau materi ajar agar peserta didik "tahu apa."

Dimana hasil akhirnya adalah peningkatan dan keseimbangan antara kemampuan untuk menjadi manusia yang baik (soft skills) dan manusia yang memiliki kecakapan dan pengetahuan untuk hidup secara layak (hard skills) dari peserta didik yang meliputi aspek kompetensi sikap, pengetahuan, dan keterampilan.

Kurikulum 2013 menekankan pada dimensi pedagogik modern dalam pembelajaran, yaitu menggunakan pendekatan ilmiah. Pendekatan ilmiah (scientific appoach) dalam pembelajaran sebagaimana dimaksud meliputi mengamati, (Observing) menanya(Questioning), menalar (Associating) , mencoba (Experimenting) membentuk jejaring (Networking) untuk semua mata pelajaran.

Dengan demikian, Kurikulum 2013 ini harus tetap berjalan karena lebih memudahkan guru dan peserta didik dalam pelaksanaan pembelajaran. Aktivitas terbanyak adalah pada peserta didik, guru sebagai inspirator, motivator dan fasilitator dalam membimbing siswa.

\section{Tugas Guru Sebagai Inspirator}

Sebagai inspirator guru harus dapat memberikan inspirasi atau petunjuk yang baik bagi kemajuan siswa. Guru harus memberikan petunjuk kepada siswa bagaimana cara belajar yang baik, media apa yang dapat digunakan dalam proses pembelajaran, sehingga hal tersebut akan melahirkan sebuah inspirasi dan dalam diri siswa tersebut untuk terus belajar guna meraih prestasi. Maka dari itu kita sebagai calon pendidik harus berkepribadian baik, religious, bermoral dan bermartabat agar peserta didik dapat menginspirasi kita sebagai pendidiknya.

Namun dalam dunia pendidikan peran guru sangatlah penting selain nilai nilai diatas guru pun harus mempunyai menjadi guru kreatif, menjadi seorang guru yang kreatif saat ini tampaknya sudah menjadi suatu keharusan. Sebab, guru yang kreatif akan mampu menciptakan proses pembelajaran yang memudahkan peserta didik menerima materi yang disampaikan dengan proses yang menyenangkan. Selain itu, kreatifitas adalah salah satu modal untuk menjadi guru profesional.

Selama ini ada banyak memang guru yang sudah mampu menjadi inspirator bagi murid-muridnya. Namun peran tersebut masih dianggap bukan hal yang utama. Cukup mendidik dan mengajar, memberi ilmu, guru merasa sudah memenuhi sebagian

besar tugasnya.

Menurut Kamus Besar Bahasa Indonesia kata "inspirasi” adalah kata benda 
yang berarti "ilham". Sedangkan kata "ilham" sendiri memiliki tiga arti yakni petunjuk Tuhan yang timbul di hati, berarti pula pikiran (angan-angan) yang timbul dari hati atau bisikan hati dan bermakna pula sesuatu yang menggerakkan hati untuk mencipta (mengarang syair, lagu, dsb). Dalam hal ini berarti seorang guru harus mampu membangkitkan pikiran atau angan-angan muridnya untuk melakukan sesuatu atau menjadi sesuatu yang positif (cita-cita atau keinginan). Guru juga harus bisa menggerakan hati anak didiknya untuk menciptakan sesuatu, membuat sesuatu, berusaha, berjuang dan mengikuti sesuatu yang diyakininya benar dan baik.

Guru sebagai pemberi inspirasi belajar harus mampu memerankan diri dan memberikan inspirasi sesuai dengan apa yang dipelajari. Membangkitkan ide, pemikiran, gagasan, optimesme dan keharmonian dalam belajar dibutuhkan sarana dan prasarana yang mendukung.

Ada 3 (tiga) pendekatan yang bisa dilakukan oleh guru dalam proses pembelajaran dikelas agar menjadi sumber inspirasi atau pemberi inspirasi :

1. Melalui Pendekatan Kecerdasan Emosional

misalnya dengan selalu menebarkan energi positif pada anak didik, toleransi terhadap ketidaksempurnaan, dan mencintai sepenuh hati anak didik dengan perbedaan yang dimiliki mereka.

2. Melalui Pendekatan Kecerdasan Spiritual

Guru bisa menanamkan kepada setiap anak didik/siswa bahwa setiap yang dilakukan oleh kita manusia adalah bernilai ibadah dan sebagai manusia harus bisa memberi manfaat bagi manusia yang lain.

3. Melalui Pendekatan Kecerdasan Sosial

Cara yang bisa dilakukan adalah dengan mempraktekan 5 S (senyum, sapa, salam, sabar dan syukur). Pendekatan di atas sebagai motivasi bagi kita untuk bisa berbuat lebih bayak dan lebih baik.

Untuk itulah pemerintah membuat standar kompetensi guru yang meliputi :

\section{? Personal / kepribadian}

Kemampuan kepribadian yang mantap, stabil, dewasa, arif, berwibawa, berakhlak mulia yang menjadi teladan bagi peserta didik.

? Profesional

Kemampuan penguasaan materi pembelajaran secara luas dan mendalam yang memungkinkan guru dapat membimbing peserta didik untuk memenuhi standar kompetensi yang ditetapkan dalam Standar Nasional Pendidikan.

? Pedagogik

Kemampuan mengelola peserta didik yang meliputi pemahaman terhadap peserta didik, perancangan dan pelaksanaan pembelajaran, evaluasi hasil belajar, serta 
pengembangan peserta didik untuk mengaktualisasikan berbagai potensi yang dimiliki.

\section{] Sosial}

Kemampuan pendidik sebagai bagian dari masyarakat untuk berkomunikasi dan bergaul secara efektif dengan peserta didik, sesama pendidik, tenaga kependidikan, orang tua/wali peserta didik, dan masyarakat sekitar.

\section{Guru Sebagai Motivator}

MC. Donald dalam Nashar menjelaskan, bahwa "motivasi adalah suatu perbuatan energy dalam diri seseorang yang ditandai dengan timbulnya perasaan dan reaksi untuk mencapai tujuan." Dalam kegiatan belajar motivasi dapat dikatakan sebagai seluruh daya penggerak dalam diri siswa yang menimbulkan, memberikan, dan menjamin kelangsungan arah kegiatan belajar. Siswa yang tidak mempunyai motivasi tidak mungkin akan melakukan aktifitas belajar.

Motivasi terbagi menjadi dua bagian, yaitu :

1. motivasi intrinsik, adalah sebuah motivasi yang lahir dari diri pribadi seseorang

2. motivasi ekstrinsik, adalah motivasi yang berasal dari luar diri seseorang. Sebagai motivator guru harus dapat membangkitkan motivasi siswa khususnya siswa yang belum memiliki motivasi diri sehingga secara perlahan akan lahir suatu kesadaran dalam dirinya untuk mengantarkannya kepada pintu kesuksesan.

\section{Guru Sebagai Fasilitator}

Jika prestasi belajar adalah hasil, maka belajar merupakan prosesnya. Dalam proses itu, siswa akan menemui berbagai rintangan. Di sinilah arti penting fasilitator. Fasilitator adalah orang yang menyediakan fasilitas. Fasilitator dalam konsep belajar mandiri, guru dan sekolah tidak lagi menjadi titik pusat kegiatan, tetapi lebih bersifat sebagai pendukung kebutuhan siswa (1997:275).

Wina Senjaya, mengatakan bahwa agar guru dapat mengoptimalkan perannya sebagai fasilitator, maka guru perlu memahami hal-hal yang berhubungan dengan pemanfaatan berbagai media dan sumber belajar. Dari ungkapan ini, jelas bahwa sebagai fasilitator, guru mutlak perlu menyediakan sumber dan media belajar yang cocok dan beragam dalam setiap kegiatan pembelajaran dan tidak menjadikan dirinya sebagai satu-satunya sumber belajar bagi siswa. Sebagai gambaran dalam ilmu sosial guru dapat memberikan tugas siswa dengan menganalisa fenomena kehidupan sosial yang terjadi pada lingkungannya maupun lingkungan bernegara melalui majalah, koran, televise, internet, dan fenomena kehidupan sosial seharihari sehingga siswa akan lebih banyak meluangkan waktunya untuk belajar dengan pengalaman hidup yang ia geluti 
Prof. Dr. Made Pidarta (1997:271) menjelaskan bahwa perilaku-perilaku yang perlu diperhatikan para pendidik sebagai fasilitator adalah sebagai berikut:

? Pendidik bertindak sebagai mitra

? 3 Melaksanakan disiplin yang permisif, ialah memberi kebebasan bertindak asal semua peserta didik aktif belajar

[? Memberi kebebasan kepada semua peserta didik untuk mengaktualisasikan potensi mereka masing-masing

[? Mengembangkan cita-cita riil para peserta didik atas dasar pemahaman mereka tentang diri sendiri

? Melayani pengembangan bakat setiap peserta didik

? 2 Melakukan dialog atau bertukar pikiran secara kritis dengan peserta didik

?] Memberi kesempatan kepada para peserta didik untuk berkreasi

? Mempergunakan metode penemuan

?] Mempergunakan metode pembuktian.

\section{Simpulan}

Guru sebagaimana kita ketahui, juga sebagai pendidik adalah bukan sekedar penyampai materi dan hanya pentransfer ilmu pengetahuan kepada peserta didik. Tetapi guru mampu memberikan pemahaman terhadap siswa tentang suatu materi tersebut karena ia adalah sebagai pembimbing, pemberi teladan, moderator, modernisator, peneliti, atau paling tidak sebagai inspirator bagi siswa, dan yang lebih penting lagi adalah membentuk kepribadian.

Dengan demikian, guru yang mengambil peran sebagai inspirator, secara langsung dituntut untuk memiliki pengetahuan dan wawasan yang luas, luwes dalam berkomunikasi, rendah hati, selalu ingin belajar dan bekerja keras, fleksibilitas dalam bergaul, berani bersikap, memiliki prinsip dalam kebenaran, dan yang paling utama tidak merasa bosan menjadi seorang pendidik.

Dalam era globalisasi ini dunia pendidikan sangatlah berpengaruh terhadap berkembangnya suatu Negara agar mempunyai sumber daya manusia yang berkualitas yang bisa bersaing dengan Negara lain. Namun dalam islam pendidikan sangatlah penting adanya seorang guru panutan untuk bisa menjadi sumber pentransfer ilmu pengetahuan selain itu gurupun berperan sebagai pembimbing, pemberi teladan, moderator, modernisator, peneliti, dan sebagai pemberi inspirasi bagi siswanya.

Maka dari itu seorang pendidik harus memenuhi standar kompetensi guru dan tentunya guru yang bisa berperan sebagai guru professional dengan telah memenuhi semua aspeknya dan salah satunya ialah peran guru sebagai inspirator dalam memberikan inspirasi kepada para siswanya. 
Dari semua kriteria guru tersebut, yang paling utama adalah guru harus memberikan teladan (uswah) yang baik untuk para peserta didik agar guru menjadi panutan para peserta didiknya. Dalam ruang lingkup sekecil apapun hingga sebesar apapun. Karena tujuan pendidikan bisa tercapai oleh peranan yang cukup andil dari seorang guru.

\section{DAFTAR PUSTAKA}

Miftakhu Rosyad, Ali, Darmiyati Zuchdi, Kabupaten Indramayu, and Jawa Barat. "SMP N2 Juntinyuat 2 Universitas Negeri Yogyakarta THE ACTUALIZATION OF CHARACTER EDUCATION BASED ON SCHOOL CULTURE IN SOCIAL STUDIES LEARNING IN JUNIOR HIGH SCHOOL." Harmoni Sosial: Jurnal Pendidikan IPS 5, no. 1 (2018): 79-92. http://journal.uny.ac.id/index.php/hsjpi.

Mumin, U Abdullah. "PENDIDIKAN TOLERANSI PERSPEKTIF PENDIDIKAN AGAMA ISLAM (TELAAH MUATAN PENDEKATAN PEMBELAJARAN DI SEKOLAH)." Al-Afkar, Journal For Islamic Studies 2, no. 1 (2018): 15-26.

Ridwan, Amin. "Peran Guru Agama Dalam Bimbingan Konseling Siswa Sekolah Dasar." Risâlah, Jurnal Pendidikan Dan Studi Islam 4, no. 1 (2017): 1-13.

Rosyad, Ali Miftakhu. "Al-Afkar, Journal for Islamic Studies URGENSI INOVASI PEMBELAJARAN DALAM PENDIDIKAN AGAMA ISLAM Al-Afkar, Journal for Islamic Studies THE URGENCY OF LEARNING INNOVATION ON ISLAMIC RELIGIOUS STUDY" 3, no. 1 (2019). https://doi.org/10.5281/zenodo.2546882.

- - - "The IMPLEMENTASI NILAI-NILAI MULTIKULTURALISME MELALUI PEMBELAJARAN PENDIDIKAN AGAMA ISLAM (THE IMPLEMENTATION OF MULTICULTURALISM VALUES THROUGH LEARNING OF ISLAMIC RELIGION EDUCATION)." Risâlah, Jurnal Pendidikan Dan Studi Islam 5, no. 1 (2019): 1-18.

Rusydi, Ibnu. "Paradigma Pendidikan Agama Integratif-Transformatif." Jurnal 
Pendidikan Islam, 1970. https://doi.org/10.14421/jpi.2011.11.105-120.

Darmaningtyas, Pendidikan Pada dan Setelah Krisis, (Cet. I: Yogyakarta : Pustaka Pelajar, 1999), hal. 4

Haidar Putra Daulay, Pendidikan Islam dalam Sistem Pendidikan Nasional di Indonesia, (Cet.I : Jakarta : Kencana, 2004), hal. 82

Al-Magribi bin as-Said Al-Magribi,"Kaifa Turabbi Waladan” diterjemahkan oleh Zaenal Abidin dengan Judul : Begini Seharusnya Mendidik Anak, (Jakarta: Darul Haq, 2004), hal. 154

M. Ali Hasan, Kumpulan Tulisan M. Ali Hasan, Cet.I: Jakarta : Siraja, 2003), hal. 93

Maman Faturrohman, Al-Qr'an Pendidikan..., hal. 3

Maman Faturrohman, Al-Qur'an Pendidikan dan Pengajaran, (Cet. I ; Bandung : Pustaka Madani, 2007), hal. 25

Mohammad Surya, Percikan Perjuangan Guru, (Cet.I : Semarang : Aneka Ilmu, 2003), hal. 234

Ramayulis, Metodologi Pengajaran Agama Islam, (Jakarta : Kalam Mulia, 1990), hal. 29

Zakiah Daradjat, dkk, Metodik Khusus Pengajaran Agama Islam, (Jakarta: Sinar Grafika Offset, 1995), hal. 172

Zakiah Daradjat, dkk, Metodik Khusus Pengajaran Agama Islam, hal. 175 